\title{
Soil, Vegetation, and Hydrologic Responses to Grazing Management at Fort Stanton, New Mexico
}

\author{
N. DEDJIR GAMOUGOUN, ROGER P. SMITH, M. KARL WOOD, AND REX D. PIEPER
}

\begin{abstract}
The purpose of this study was to evaluate vegetation, soils, infiltration rates, and sediment production as they relate to livestock exclusion, continuous heavy grazing, continuous moderate grazing, and rotation grazing on a homogeneous plant-soil complex. The exclusion of livestock resulted in infiltration rates significantly higher than when the pastures were grazed in any system. No differences were found between heavily and moderately stocked pastures. This was attributed to organic matter additions from forbs that replaced grasses when the area was heavily grazed. The rotation treatment had infiltration rates that were lower than the exclosures or continuous grazing treatments. Sediment production from inter rill crosion was similar in all treatments except when the livestock were concentrated into a fourth of the rotation system's area, which resulted in higher sediment levels.
\end{abstract}

Better use and protection of limited soil, vegetation, and water resources are vital to the welfare, if not survival, of civilization as global population continues to expand. Development of these resources on rangeland watersheds has been largely neglected, although these watersheds occupy $40 \%$ of the earth's land surface$80 \%$ of which lies within arid and semiarid regions. In these drier regions, overgrazing and short-term droughts drive a cycle of decreasing soil surface micro-roughness and macroporosity, decreasing water infiltration, increasing surface runoff and evaporation, increasing sediment production, decreasing vegetation production, and increasing land barrenness (Dixon and Simanton 1977). This cycle leads to desertification and irreversible deterioration of soil, vegetation, and water resources. Infiltration rate is an important process on rangeland watersheds because it influences soil water content, sediment, and on-site vegetation production. It should be controlled by resource managers through the manipulation of vegetation. Grazing systems bascd on assumptions that they improve production, cover, and composition of vegetation have been recommended as "best management practices" for improvement of rangeland watershed conditions (Wood 1980). Although this recommendation appears valid, only a small amount of investigation has been carried out to quantitatively describe effects of grazing systems on rangeland watersheds through time (Knight et al. 1980, McCalla et al. 1984). No such investigation has been conducted in New Mexico.

The objective of this study was to describe quantitatively the influence of selected grazing schemes and grazing exclusion on infiltration rates, sediment production, forage production, microrelief, plant cover, and litter cover through time.

\section{Study Area}

This 3-year (1979, 1980, and 1981) study was conducted on a mesa on the Fort Stanton Experimental Range in Lincoln County,

\footnotetext{
At the time of this study the authors were graduate research assistants, associate professor of watershed management, and professor of range ecology, Department of Animal and Range Sciences, New Mexico State University, Las Cruces 88003.

This report is published with approval of the Director, New Mexico Agricultural Experiment Station, as JA 1007. The authors wish to acknowledge the support of the Range Improvement Task Force, and Richard Brown, Mark Wondzell, and Thomas Phillips for assistance in collecting data.

Manuscript accepted March 12, 1984
}

in south-central New Mexico at latitude $33^{\circ} 30^{\prime}$ North and longitude $105^{\circ} 31^{\prime}$ West. The Range is in foothills transition between shortgrass prairie and pinyon-juniper-oak types. Elevation of the 10,522 -ha ranch varies from 1,890 to $2,286 \mathrm{~m}$ and topography consists of rolling hills and flat-topped mesas separated by deep canyons.

Mesa tops and bottomlands were dominated generally by herbaceous vegetation, whereas slopes and rocky ridges were dominated by woody species (Pieper et al. 1971). The major forage species was blue grama (Bouteloua gracilis (H.B.K.) Lag. ex Steud.), which was dominant or codominant on all sites. Other important grasses included wolftail (Lycurus phleoides H.B.K.), sand dropseed (Sporobolus cryptandrus (Torr.) Gray), mat muhly (Muhlenbergia richardsonis (Trin.) Rydb.), ring muhly (Muhlenbergia torreyi (Kunth) Hitchc.), red three awn (Aristida longiseta Rydb.), galleta ( Hilaria jamesii (Torr.) Benth.), Hall's panic (Panicum hallii Vasey), and sideoats grama (Bouteloua curtipendula (Michx.) Torr.). Common forbs were Carruth sagewort (Artemisia carruthii Wood), scarlet globemallow (Sphaeralcea coccinea (Pursh) Rydb.), Dakota vervain (Verbena bipinnatifida Nutt.) and Rocky Mountain zinnia (Zinnia grandiflora Nutt.). Important woody species included pinyon pine (Pinus edulis Engelm.), single-seeded juniper (Juniperus monosperma (Englem.) Sarg.), walking stick cholla (Opuntia imbricata (Haw.) DC.), and wavey-leaf oak (Quercus undulata Torr.). Also present were bottlebrush squirreltail (Sitanion hystrix (Nutt.) J.G. Smith) and broom snakeweed (Xanthocephalum sarothrae (Pursh) Skinners).

Soils were of the Dioxice series which is in the fine-loamy, mixed, mesic family of Aridic calciustolls. This soil was found in pastures of each treatment. This allowed a valid comparison to be made of treatments (Pieper et al. 1978).

The average annual precipitation recorded at headquarters was $383.5 \mathrm{~mm}, 65 \%$ of which generally occurred from June through September. Precipitation during summer was primarily from convection-type storms and rainfall was often intense and localized. Precipitation during 1979 fell earlier than usual (Fig. 1). May and June are normally dry ( 23 and $32 \mathrm{~mm}$, respectively) but about 46 and $70 \mathrm{~mm}$ was recorded during these 2 respective months in 1979.

Temperatures were mild, with an annual mean of $11.1^{\circ} \mathrm{C}$. The range was from a mean minimum of $-6.7^{\circ} \mathrm{C}$ in January to a mean maximum of $18.9^{\circ} \mathrm{C}$ in July. The average frost-free period was 161 days; the average date of last frost was May 2 and the average date of the first frost was October 10 (U.S. Weather Bureau).

\section{Methods}

Four grazed pastures and an area which had been excluded from livestock grazing since 1952 were selected as study sites. Grazed pastures included 1 continuously grazed at a heavy stocking rate, 1 continuously grazed at a moderate stocking rate, and 2 pastures from a four-pasture, one-herd rotation system stocked at a heavy rate. Stocking rate of the moderate continuous pasture (23.13 ha/AU) was about $25 \%$ lower than the heavy continuous and rotation pastures. In the rotation system livestock were moved 


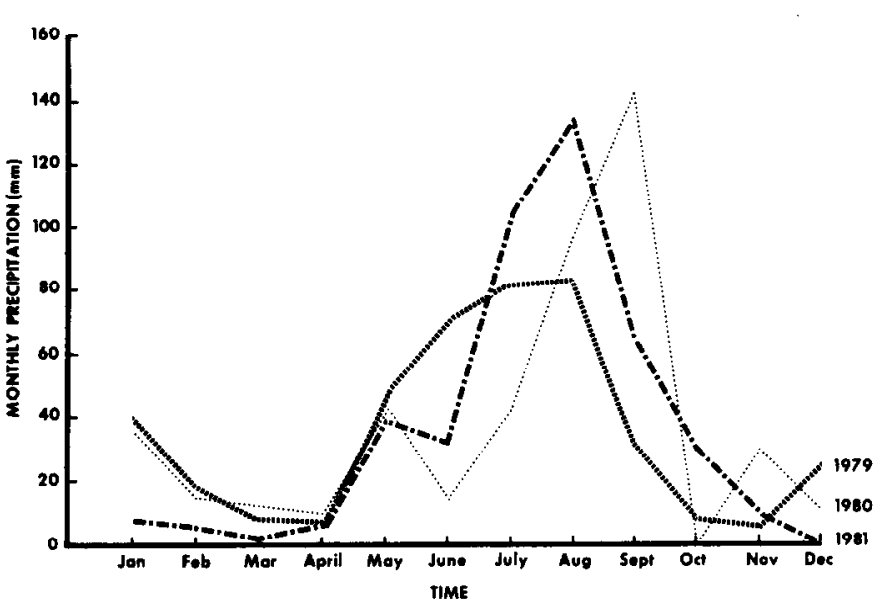

Fig. 1. Monthly precipitation for 1979, 1980, and 1981 .

about every 4 months, and data were collected immediately after one pasture had been rested for 12 months and immediately after another pasture had been grazed for the full grazing period of 4 months. This grazing scheme had been in effect since 1969 (Pieper et al. 1978). In 1980 and 1981 , the rotation system was changed to a four-pasture, three-herd system stocked at one-third the heavy rate, except in summer (May through August) when the animals were concentrated in 1 pasture for breeding purposes. In this four-pasture, three-herd system, livestock were moved about every 3 months, and all the data were collected immediately after one pasture had been rested for 3 months and immediately after another pasture had been grazed for the full grazing period of 9 months (Pieper personal communication).

Within each pasture, 3 subsample areas were randomly located. On each a mobile infiltrometer (Blackburn et al. 1974) was used to simulate rainfall on $4,1-\mathrm{m}^{2}$ plots. Simulated rainfall was applied to the plots at the existing soil moisture level until runoff occurred. Plots were then covered with clear polyethylene plastic to prevent evaporation, insuring fairly uniform soil moisture conditions for a second simulated rainfall application which occurred 24 hours later. Data collected following the first application of simulated rainfall showed trends similar to data collected when the soil was at field capacity but they were more variable. Therefore, only results of the second readings are reported here.

Simulated rainfall rate was $7.5 \mathrm{~cm} / \mathrm{hr}$ for a period of 45 minutes. This rate represented a high intensity storm for the area. Preliminary tests showed $\mathbf{4 5}$ minutes was required for the infiltration rate to become fairly constant when simulated rainfall was applied to plots at field capacity (Smith 1980). Run-off from plots was collected and pumped into plastic bottles where it was weighed at 5-minute intervals and converted into centimeters of runoff. Average infiltration rate was determined by subtracting measured precipitation at the given time intervals. This procedure does not account for losses due to interception and evaporation, which were probably not significant.
Runoff collected from each plot was thoroughly agitated and a 1 -liter subsample removed. Sediment was filtered off the subsample, dried at $100^{\circ} \mathrm{C}$ for 24 hours, weighed, and converted to sediment yield in kilograms per hectare.

Foliar cover estimates of grasses, forbs, rock, litter, and bare ground were made in each plot using the line intercept method. The tape measure was stretched across the metal runoff frame 6 times at 13-cm intervals. Readings were taken on all plots after the second simulated rainfall. Foliar cover was the cover that would intercept a raindrop. Rock was pebble sized particles or larger. Grasses and forbs, both standing live and dead, were clipped at $1.5-\mathrm{cm}$ stubble height, and litter was collected from each $1-\mathrm{m}^{2}$ plot. The material was dried at $60^{\circ} \mathrm{C}$ for 1 week and weighed.

A micro-relief meter was used to detemine surface roughness in each plot. The micro-relief meter consisted of 21 metal pins, spaced $4.35 \mathrm{~cm}$ apart on a vertical board which slid up and down according to the height of the ground. The top of the pins corresponded to a graduated scale which showed height difference in millimeters. The variation was obtained by averaging differences for 3 readings taking per plot.

Data normality was determined by tests for skewness and kurtosis. Analysis of variance, based on a randomized design, was used to determine if any significant difference existed between means for both the dependent and independent variables. Within treatments variation (variation among subplots) was allocated to the residual for testing differences $(P \leq .95)$ among treatments. If differences existed between the treatment or yearly means, Tuckey's wprocedure was used to separate the means (Steel and Torrie 1980).

\section{Results and Discussion}

\section{Foliar Cover}

Percentage of foliar cover across all treatments was highest in $1979(50 \%)$ and $1981(54 \%)$ and lowest in $1980(14 \%)$. In 1980 precipitation did not fall until after the sampling period. Across all years foliar cover percentages were highest in the moderately stocked pasture (50\%), similar to the exclosure's value of $43 \%$. Foliar cover in the exclosure was also similar to values in the heavily stocked pasture $(40 \%)$, the rested rotation pasture $(35 \%)$, and the grazed rotation pasture (36\%). Table 1 shows foliar cover for each treatment within each year.

\section{Standing Biomass}

The average standing biomass in all pastures for $1979(1,360$ $\mathrm{kg} / \mathrm{ha})$ was significantly greater than for $1980(750 \mathrm{~kg} / \mathrm{ha})$ and $1981(876 \mathrm{~kg} / \mathrm{ha})$. This was the result of above-normal precipitation which fell early in the 1979 growing season. When all years were combined, the most standing biomass was found in the exclosure $(1,550 \mathrm{~kg} / \mathrm{ha})$ followed by the heavily stocked pasture $(1,163$ $\mathrm{kg} / \mathrm{ha})$, the grazed rotation pasture $(712 \mathrm{~kg} / \mathrm{ha})$, the rested rotation pasture $(687 \mathrm{~kg} / \mathrm{ha})$, and the moderately stocked pasture $(625$ $\mathrm{kg} / \mathrm{ha}$ ). Yields of all of the grazed pastures were statistically similar, and the heavily stocked pasture was similar to the exclosure. The large amounts of vegetation in the heavily stocked pasture can be explained by considering the species composition. Plant component of the moderately stocked pasture was chiefly grasses while

Table 1. Mean vegetation and soil characteristics within the exclosure and each grazing treatment.

\begin{tabular}{|c|c|c|c|c|c|c|c|c|c|c|c|c|c|c|c|}
\hline \multirow[b]{2}{*}{ Vegetation or soil variable } & \multicolumn{5}{|c|}{1979} & \multicolumn{5}{|c|}{1980} & \multicolumn{5}{|c|}{1981} \\
\hline & $\overline{\mathrm{XX}^{\prime}}$ & $\mathbf{M}$ & $\mathrm{H}$ & $\mathbf{R R}$ & RG & $\mathrm{EX}$ & $\mathbf{M}$ & $\mathbf{H}$ & RR & RG & EX & $\mathbf{M}$ & $\mathrm{H}$ & $\mathbf{R R}$ & RG \\
\hline $\begin{array}{l}\text { Foliar cover }(\%) \\
\text { Standing biomass }(\mathrm{kg} / \mathrm{ha}) \\
\text { Bare ground }(\%) \\
\text { Litter cover }(\%) \\
\text { Micro-relief variability }(\mathrm{cm})\end{array}$ & $\begin{array}{c}58^{\mathrm{ab2}} \\
2103^{\mathrm{a}} \\
36^{\mathrm{bc}} \\
3^{\mathrm{a}} \\
.7^{\mathrm{a}}\end{array}$ & $\begin{array}{r}61^{\mathrm{a}} \\
1127^{\mathrm{c}} \\
32^{\mathrm{c}} \\
2^{\mathrm{a}} \\
.6^{\mathrm{a}}\end{array}$ & $\begin{array}{r}38^{\mathrm{c}} \\
1647^{\mathrm{b}} \\
52^{\mathrm{a}} \\
4^{\mathrm{a}} \\
.7^{\mathrm{a}}\end{array}$ & $\begin{array}{c}40^{\mathrm{bc}} \\
987^{\mathrm{c}} \\
48^{\mathrm{ab}} \\
2^{\mathrm{a}} \\
.6^{\mathrm{a}}\end{array}$ & $\begin{array}{c}47^{\mathrm{bc}} \\
950^{\mathrm{c}} \\
44^{\mathrm{ab}} \\
2^{\mathrm{a}} \\
.6^{\mathrm{a}}\end{array}$ & $\begin{array}{r}18^{\mathrm{a}} \\
997^{\mathrm{a}} \\
79^{\mathrm{ab}} \\
3^{\mathrm{ab}} \\
.8^{\mathrm{a}}\end{array}$ & $\begin{array}{c}16^{\mathrm{a}} \\
256^{\mathrm{a}} \\
79^{\mathrm{ab}} \\
1^{\mathrm{a}} \\
.4^{\mathrm{a}}\end{array}$ & $\begin{array}{c}14^{\mathrm{a}} \\
672^{\mathrm{a}} \\
75^{\mathrm{b}} \\
6^{\mathrm{b}} \\
.7^{\mathrm{a}}\end{array}$ & $\begin{array}{c}12^{\mathrm{a}} \\
962^{\mathrm{a}} \\
85^{\mathrm{ab}} \\
1^{\mathrm{b}} \\
.5^{\mathrm{a}}\end{array}$ & $\begin{array}{c}11^{\mathrm{a}} \\
760^{\mathrm{a}} \\
86^{\mathrm{a}} \\
1^{\mathrm{b}} \\
.6^{\mathrm{a}}\end{array}$ & $\begin{array}{c}54^{\mathrm{a}} \\
1548^{\mathrm{a}} \\
41^{\mathrm{ab}} \\
5^{\mathrm{a}} \\
2.0^{\mathrm{a}}\end{array}$ & $\begin{array}{c}73^{\mathrm{a}} \\
527^{\mathrm{bc}} \\
27^{\mathrm{b}} \\
1^{\mathrm{b}} \\
1.0^{\mathrm{b}}\end{array}$ & $\begin{array}{c}63^{\mathrm{a}} \\
1203^{\mathrm{ab}} \\
30^{\mathrm{b}} \\
6^{\mathrm{a}} \\
1.1^{\mathrm{b}}\end{array}$ & $\begin{array}{c}46^{\mathrm{a}} \\
696^{\mathrm{bc}} \\
53^{\mathrm{a}} \\
1^{\mathrm{b}} \\
.9^{\mathrm{b}}\end{array}$ & $\begin{array}{c}42^{\mathrm{a}} \\
351^{\mathrm{c}} \\
54^{\mathrm{a}} \\
4^{\mathrm{ab}} \\
1.1^{\mathrm{b}}\end{array}$ \\
\hline
\end{tabular}

IEX, exclosure; M, moderately stocked and continuously grazed; $H$, heavily stocked and continuously grazed; $R R$, rested rotation; $R G$, grazed rotation.

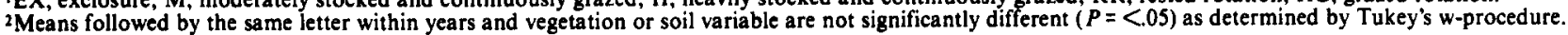


the heavily stocked pasture contained a high percentage of broadleaf forbs and broom snakeweed. The standing biomass was similar.

In the wet year of 1979 the exclosure had a much higher production than the other pastures and an abundance of forbs emerged in the heavily stocked pasture (Table 1). Exclusion of grazing did not favor standing biomass over rotation and heavily stocked pastures in the dry year of 1980. Standing biomass was lower in 1980 than 1979 in the exclosure and in the moderate and heavily stocked pastures, but production recovered in 1981. Meanwhile, the rotation pasture continued to show decreased production from 1980 through 1981.

\section{Litter Cover}

Litter cover was greatest in the heavily stocked, continuously grazed pasture each year (Table 1), although the differences were not significant. This was attributed to trampling, which detached the standing dead and live plant material. More litter cover was in the exclosure. Overall, the litter cover was small with the largest value being only $6 \%$.

\section{Bare Ground}

Bare ground represented the reciprocal of all combined plant cover components. Bare ground percentages were highest during the driest year, 1980. Large areas of bare ground were found in the exclosure and were attributed to mature bunch grasses which may be competing for soil moisture beyond the foliar area. The rotation pasture consistently had as much or more ground than other pastures.

\section{Micro-relief}

Differences in micro-relief were not significant among pastures across all years. Within years the micro-relief was greater in the exclosure, in the heavily stocked, and grazed rotation pastures than in the others (Table 1). Increased roughness in heavily stocked and grazed rotation pasture was the result of livestock hoof action during wet periods. The rougher surface in the exclosure was the result of blue grama plants attaining a bunchgrass form while the same species was more of a flat sodgrass outside the exclosure.

\section{Infiltration Rate}

Averaged across all treatments, terminal infiltration rates (after 45 minutes) were significantly lower in $1979(6.0 \mathrm{~cm} / \mathrm{hr})$ than the rates in $1980(6.9 \mathrm{~cm} / \mathrm{hr})$ and $1981(6.7 \mathrm{~cm} / \mathrm{hr})$. Values during these last 2 years were similar. These year-to-year fluctuations are attributed to the different amounts of precipitation following the spring thaw. Soils were fluffy or loose at the end of winter because of the shrink-swelling effects of freezing and thawing. Late spring and summer rains changed this to a crusted and more dense epipedon. Most precipitation during 1980 fell in August and September which rendered the loose soil conditions throughout June and July. Lack of precipitation during May and June of 1981 (40 $\mathrm{mm}$ and $32 \mathrm{~mm}$, respectively) was not as severe as in 1980, but not nearly as great as in 1979. During the rainy summer of 1979 , the soil became crusted and acted as an impeding layer with higher bulk density and reduced porosity (unpublished data on file with M.K. Wood). These conditions contributed to increased runoff.

Terminal infiltration rates were significantly higher $(6.9 \mathrm{~cm} / \mathrm{hr})$ in the exclosure for each year and when averaged across years (Fig. 2). The heavily and moderately stocked, continuously grazed pastures had similar values $(5.5$ and $5.4 \mathrm{~cm} / \mathrm{hr}$, respectively) which were significantly higher than the rested and grazed pastures in the rotation system ( 4.7 and $43 . \mathrm{cm} / \mathrm{hr}$, respectively).

Meaningful comparisons were made by examining rates between treatments within the same year (Fig. 2). During the moist growing season of 1979, infiltration rates in the exclosure were not affected as much by changes in soil surface characteristics as were pastures subjected to grazing treatments. The exclosure had enough potential to continue to absorb most precipitation, as it did in 1980 and 1981. The continuously grazed pastures in 1979 had infiltration rates which were higher than those in rested and grazed rotation pastures.
INFILTRATION RATE (CM/HR)
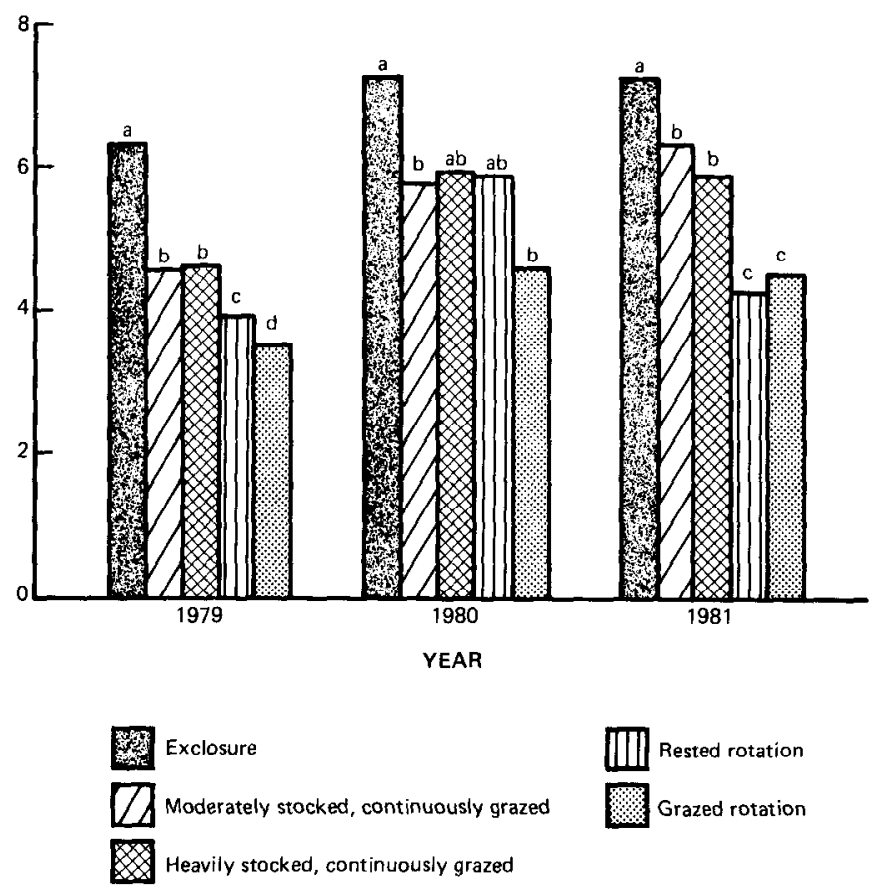

Fig. 2. Mean wet final infiltration rates $(\mathrm{cm} / \mathrm{hr})$ in each pasture within years (means indicated by the same letter within each year are not significantly different at the $95 \%$ level as determined by Tukey's w-procedure).

Similarity between the moderately and heavily stocked, continuously grazed pastures can be explained by comparing percentages of foliar cover and standing biomass (Table 1). Although foliar cover was highest in the moderately stocked pasture, standing biomass was highest in the heavily stocked pasture due to the abundance of tall forbs with high lcaf-area indices. Therefore, standing biomass may offset influences of foliar cover and hydrologic condition, and may not necessarily correlate with range conditions that are suitable for livestock. In this situation, the heavily stocked pasture exhibited a lower seral stage than did the moderately stocked pasture, but infiltration rates were similar. This situation persisted for all 3 years and was supported by correlation analysis (unpublished data on file with M.K. Wood). The rotation system was started in 1969 on an area that had not been grazed since 1952. The stocking rate was heavy, but these pastures have never regressed to the seral stage of the heavily stocked, continuously grazed pasture. Some confounding effects existed because the heavily stocked, continuously grazed pasture received slightly more precipitation during some years because it is located closer to a mountain range. Also livestock movements within pastures were variable with some higher concentrations of animals in the sampled area of the rotation pastures over the areas of the same soil type in the heavily and moderately stocked, continuously grazed situations. This conclusion is supported by the similarity in infiltration rates, and from vegetation cover, standing biomass, and soil micro-relief data.

\section{Sediment Production}

Sediment production historically has been one of the components of the ecosystem with the most variation (Wood and Blackburn 1981). Our data concur (Fig. 3). This shows variations of sediment production within each year for each pasture. The importance of protective vegetation can be seen in year-to-year fluctuations, especially in the grazed rotation pasture. The rested rotation pasture had an opposite trend from wet to dry years. Of the 3 pastures being rested in the rotation system, the 1 sampled had 


\section{SEDIMENT PRODUCTION (KG/HA)}
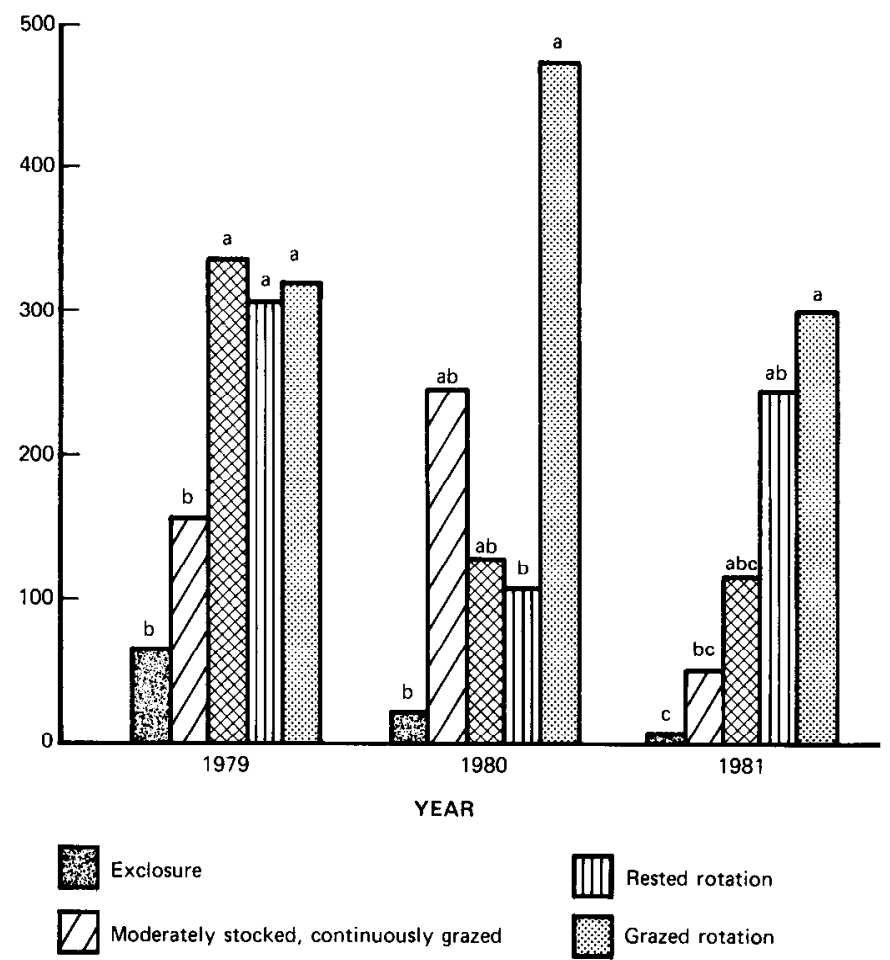

Heavily stocked, continuous!y grazed

Fig. 3. Mean wet sediment production $(\mathrm{kg} / \mathrm{hr}$ ) in each pasture within years (means indicated by the same letter withineach year are not significantly different at the 5\% level as determined by Tukey's w-procedure).pastures.

been rested longest. It is assumed that sediment production from the other two pastures was proportionately between the longest rested and the grazed rotation pastures. Therefore, the extremely high levels of sediment production may be compensated for by the resting phase of the system. The trends for the continuously grazed pastures are difficult to explain. Responses are at least partially masked by the amount of variation. Infiltration rates were similar between the continuously grazed treatments for the 3 years of the study.
When all years are combined, the lowest sediment levels were produced in the exclosure, with a mean of $34 \mathrm{~kg} / \mathrm{ha}$. Pastures with sediment production that was higher than, but different from, the exclosure and to each other include the moderately stocked, continuously grazed $(155 \mathrm{~kg} / \mathrm{ha})$, the heavily stocked, continuously grazed $(198 \mathrm{~kg} / \mathrm{ha})$, and the rested rotation $(226 \mathrm{~kg} / \mathrm{ha})$. The sediment produced as a result of concentrating the livestock into a fourth of the rotation system was $367 \mathrm{~kg} / \mathrm{ha}$, significantly higher than the exclosure and moderately stocked, continuously grazed areas.

Overall, the rotation treatment did not respond any bettcr hydrologically than the continuously grazed pasture at the same heavy stocking rate. Exclusion of grazing did not give hydrologic responses which were superior or significantly different from moderate stocking. Possibly, the exclosure is in a seral stage of rested disclimax and an optimum hydrologic condition could exist with some continuous level or systematic livestock grazing.

\section{Literature Cited}

Blackburn, W.H., R.O. Meeuwig, and C.M. Skau. 1974. A mobile infiltrometer for use on rangeland. J. Range Manage. 27:322-323.

Dixon, R.M., and J.R. Simanton. 1977. A land imprinter for revegetation of barren land areas through infiltration control. Hydrology and Water Resources in Arizona and the Southwest. 7:79-88.

Knight, R.W., W.H. Blackburn, and L.B. Merrill. 1980. Impacts of selected grazing systcms on hydrologic characteristics, Edwards Plateau, Texas. Abs. 33rd Annual Meeting Soc. Range Manage.

McCalla, G.R., W.H. Blackburn, and L.B. Merrill. 1984. Effects of livestock grazing on infiltration rates, Edwards Plateau, Texas. J. Range Manage (In Press).

Pieper, R.D., G.B. Donart, E.E. Parker, and J.D. Wallace. 1978. Livestock and vegetational response to continuous and 4-pasture, 1-herd grazing systems in New Mexico. Proc. Ist Int. Rangeland Congr. Denver, Colo.

Pieper, R.D., J.R. Montoya, and V.L. Groce. 1971. Site characteristics on pinyon-juniper and blue grama ranges in southcentral New Mexico. New Mex. Agr. Exp. Sta. Bull. 573.

Smith, R.P. 1980. The influence of different grazing practices on infiltration rates and sediment production at Fort Stanton, New Mexico. Master's thesis. New Mexico State Univ., Las Cruces,

Steel, R., G.D. and J.H. Torrie. 1980. Principles and procedures of statistics. McGraw-Hill Book Co., Inc., New York.

U.S. Weather Bureau. 1856-1976. Climatological data: New Mexico Section. Summaries and annual reports.

Wood, M.K. 1980. Impacts of grazing systems on watershed values p. 163-170. In: Proc. Grazing Manage Syst. for Southwest Rangelands Symp., Range Improvement Task Proc. New Mexico State Univ. Las Cruces.

Wood, M.K., and W.H. Blackburn. 1981. Sediment production as influenced by livestock grazing in the Texas Rolling Plains. J. Range Manage. $34: 228-231$. 